IFN Working Paper No. 1049, 2014

\title{
Superentrepreneurship and Global Imbalances: Closing Europe's Gap to Other Industrialized Regions
}

Magnus Henrekson and Tino Sanandaji 


\title{
Superentrepreneurship and Global Imbalances: Closing Europe's Gap to Other Industrialized Regions
}

\author{
Magnus Henrekson and Tino Sanandaji
}

\begin{abstract}
August 3, 2015
Abstract: The overwhelming majority of self-employed individuals are not entrepreneurial in the Schumpeterian sense. To unmistakably identify Schumpeterian entrepreneurs, we focus on self-made billionaires (in USD) from the Forbes Magazine list who became wealthy by founding new firms. In this way, we identify 996 billionaire entrepreneurs in over fifty countries during the 1996-2010 period. Interestingly, the rate of billionaire entrepreneurs per capita correlates negatively with self-employment rates. Countries with higher incomes, higher trust, lower taxes, more venture capital investment and lower regulatory burdens have higher entrepreneurship rates but less self-employment. Europe has a higher self-employment rate than the United States and East Asia. At the same time, Europe has a lower entrepreneurship rate than competitor regions. Europe underperforms in entrepreneurship despite having advantages such as a skilled labour force, good infrastructure, large markets and strong performance in technological innovation.
\end{abstract}

JEL Codes: L5; M13; O31; P14

Keywords: Entrepreneurship; Innovation; Institutions; Regulation; Self-employment

\author{
${ }^{1}$ Research Institute of Industrial Economics (IFN) \\ Box 55665 \\ SE-102 15 Stockholm \\ Phone: +46-8-665 4500 \\ Fax: +46-8-665 4599 \\ e-mail: magnus.henrekson@ifn.se \\ tino.sanandaji@ifn.se
}

\footnotetext{
${ }^{*}$ We thank Louise Johannesson and Lars Oxelheim for their valuable comments on an earlier draft of this essay. We also gratefully acknowledge financial support from Karl-Adam Bonniers Stiftelse and from the Marianne and Marcus Wallenberg Foundation.
} 


\section{Introduction}

Entrepreneurs perform a central function in today's decentralised market economies by innovating and exploring new ways to organise factors of production. They are consequently widely believed to play an important role in economic growth.

The attention afforded to entrepreneurship by policy makers and academics is also rooted in historical experience, as each wave of innovation since the eve of industrialisation has been associated with entrepreneurs such as James Watt, Andrew Carnegie, Henry Ford, Sam Walton and Bill Gates. Entrepreneurs have more recently been linked to firm performance using careful causal methods (Becker and Hvide 2013). Entrepreneurship theory is concerned with understanding the innovative process and with identifying policies that foster the creation of rapidly growing firms (Baumol 2002). The dominant view of entrepreneurship in the literature is arguably the Schumpeterian definition of the entrepreneur as an innovator and as a driver of growth (Hébert and Link 2006; Henrekson and Roine 2007).

When academics and business leaders were asked to define entrepreneurship, the most common suggestion was the creation and development of new ventures followed by innovation. In contrast, "the creation of a mom-and-pop business" was not viewed as entrepreneurship (Gartner 1990). Whether or not self-employment is synonymous with entrepreneurship is in part a question of semantics. However, because self-employment is defined by a legal employment form rather than an economic function, it is not necessarily synonymous with Schumpeterian entrepreneurship.

There is a broad consensus among European policymakers and opinion leaders that Europe suffers from an "entrepreneurship deficit", especially compared to the United States. The European Commission has declared a vision to "unleash Europe's entrepreneurial potential, to remove existing obstacles and to revolutionise the culture of entrepreneurship in Europe. It aims to ease the creation of new businesses and to create a much more supportive environment for existing entrepreneurs to thrive and grow." ${ }^{1}$ The European Union is the world's leading trade area. EU member countries account for 20 percent of world trade, despite harbouring no more than seven percent of the world population. Here and in the rest of this essay, Europe is defined as Western Europe.

One pertinent question is whether a European entrepreneurship deficit gives rise to some form of global imbalance. Innovative entrepreneurship is not only important for the country where it takes place; it reverberates throughout the entire global economic system.

\footnotetext{
${ }^{1}$ Cited from the European Commission (2013, p. 5).
} 
The development of new technological systems such as the Internet and the ensuing applications takes place simultaneously in a great many countries. Each firm can benefit from and base its own products on technologies developed anywhere in the world. If one important region underperforms relative to its inherent potential, this obviously hurts that region.

Because of the strong global interdependencies, however, underperforming regions slow down the rate of growth in other parts of the world as well.

Innovation is not easily quantifiable. ${ }^{2}$ One measure used by the OECD is the number of quality-adjusted patents relative to population. Since the year 2000, the United States has produced 30 such patents per million inhabitants, compared to 19.7 in Europe. If Europe had performed on par with the U.S., the number of new patents in the world would have increased by almost one fifth. Europe is a mature economic region. Therefore, its key economic role in the global economic system and division of labour cannot be mass production of rather standardised goods. Instead, it needs to be a leader in innovation and innovative entrepreneurship. Many European countries - notably Germany, the Netherlands, Sweden and Finland - are among the global leaders in regard to innovation in large incumbent firms.

However, when it comes to innovative entrepreneurship, Europe contributes less to the global economy.

In the European Union, the so-called Innovation Union has been launched as a key component in the EU 2020 initiative. Here the tone is one of urgency, verging on desperation: "We need to do much better at turning our research into new and better services and products if we are to remain competitive in the global marketplace and improve the quality of life in Europe. We are facing a situation of "innovation emergency'."3

There is also plenty of anecdotal evidence supporting the assertion that there have been far more entrepreneurial firms started in the post-war period that have managed to grow large in North America compared to Europe. Well-known examples include Apple, Google, Intel, FedEx, Microsoft, Wal-Mart and Amazon, firms that in the aggregate have created millions of jobs and have become world leaders in their industry. However, scattered anecdotal evidence does not constitute a sufficient basis to guide policy in the areas of innovation and entrepreneurship. We will therefore try to quantify the differences between Europe and other comparable regions using a new measure of high-impact entrepreneurship. This systematic comparison also provides a suitable platform for an informed discussion

\footnotetext{
${ }^{2}$ See Gault (2013), Hall (2011) and OECD (2010) for reviews of the literature.

${ }^{3}$ Cited from http://ec.europa.eu/research/innovation-union/index en.cfm?pg=why (accessed September 1, 2014). Bold in the original.
} 
about the most likely explanations for a European entrepreneurship deficit, should we find one.

Differences in the rate of entrepreneurship between the U.S. and Europe have been discussed in previous studies (e.g., Lerner and Schoar 2010). However, these studies tend to use measures that are more closely related to self-employment rather than Schumpeterian entrepreneurship.

There are few studies comparing Europe to the wealthiest and most technologically advanced countries in Asia. Here we define this group as Japan, South Korea, Taiwan, Singapore and Hong Kong. We will see below that the Asian economies overall outperform Europe.

The imbalance regarding entrepreneurship relative to the U.S. most likely harms the European economies. Innovative entrepreneurship not only creates high-skill jobs in the entrepreneurial firms themselves: studies show that each additional high-tech job in a city or metropolitan area on average gives rise to five other jobs (Moretti 2012; Moretti and Thulin 2013). These jobs range from advanced consultancy and educational services to low-skilled service jobs.

Entrepreneurship is also important for innovation and productivity growth. ${ }^{4}$ It is evident that the imbalance relative to the U.S., but also to Asia, works to the disadvantage of Europe. However, it may also be negative for non-European countries. Knowledge and technology differ fundamentally from physical raw materials and tangible goods. If the U.S. increased its oil production, it would harm competitor countries such as Russia and Norway because the resulting increase in the global supply of oil would lower the price. Russia's and Norway's output of oil would now be worth less than before.

In regard to knowledge and technology, matters are very different. First, knowledge and new technology are both non-rival: they can be used an infinite number of times without being used up or depreciated. Second, knowledge and technologies developed domestically need not become less valuable if they are used in other countries. Increased knowledge in one country is not necessarily a substitute for the knowledge created in other countries. It may instead be a complement that raises the value of knowledge in all countries. The fact that the microprocessor was invented in the U.S. did not harm economies in the rest of the world. On the contrary, it created an enormous number of new business opportunities for firms in other countries. Thus, technological change and new products benefit not only the countries where

\footnotetext{
${ }^{4}$ For studies documenting the importance of entrepreneurship and innovation for economic growth, see Baumol (2010), Braunerhjelm (2012), Carree and Thurik (2010) and Holcombe (2007).
} 
this innovation and production take place but also other economies in the world, which in turn can absorb and use the new knowledge as input for their own innovative entrepreneurship.

Although the extensive entrepreneurial venturing rooted in IT and the Internet has its point of gravity in the U.S., it has still greatly benefited firms and consumers in Europe. If Europe had been as innovative and entrepreneurial as the U.S., it would have benefited U.S. firms and consumers in a similar way. As a result, it is fair to discuss a genuine imbalance in entrepreneurship, which is detrimental not only to Europe itself, but also to the rest of the world.

To ascertain that policymakers are fostering entrepreneurship as efficiently as possible, one must be able to measure and quantify the rate of entrepreneurship. Similarly, if we want to evaluate how tax changes, R\&D subsidies and regulations affect entrepreneurship, it must be measurable and quantifiable. However, quantifying the rate of entrepreneurship across countries has turned out to be more difficult than one would expect. One reason is that entrepreneurship is not well and unambiguously defined. In most studies to date, the rate of self-employment has been used to measure entrepreneurship. There are some obvious merits to this approach, for example that self-employed individuals, just like Schumpeterian entrepreneurs, rarely work for someone else, operate a business and need to wrestle with issues such as risk, uncertainty (Knight 1921) and alertness to opportunity (Kirzner 1973). However, an overwhelming majority of self-employed individuals are not entrepreneurial in the Schumpeterian sense because they do not bring a new innovation to the market or plan to grow their business.

This measure has therefore been increasingly called into question. ${ }^{5}$ The most common theoretical definition of entrepreneurship is arguably the Schumpeterian definition, in which the entrepreneur is seen as a growth-oriented innovator. The concept emanates from the Austrian economist Joseph Schumpeter, who, in his classical book The Theory of Economic Development first published in German in 1911, made the entrepreneur the primus motor of capitalism.

Whether entrepreneurship is synonymous with self-employment is partly a question of semantics. In the U.S., the industries with the largest concentrations of self-employed men are construction, landscaping services, auto repair, restaurants, truck transportation, and farming. For women, the corresponding industries include private household services (cooks, maids), child day care services, restaurants and beauty salons. The overwhelming majority of

\footnotetext{
${ }^{5}$ Hurst and Pugsley (2011), Shane (2008) and Henrekson and Sanandaji (2014).
} 
small businesses in the U.S. have no employees other than the owner. Nor do most small businesses eventually grow large. Most small businesses are best described as permanently small rather than nascent entrepreneurial firms. There is no doubt that this type of firm fulfils an important role in the economy, creating jobs and producing goods and services efficiently and flexibly, but they should not be part of a measure that aims to gauge the rate of innovative entrepreneurship.

In this paper, we propose a new measure of Schumpeterian entrepreneurship - i.e., the prevalence of innovative firms with a high impact on the overall economy -to compare the rate of entrepreneurship across countries and regions. ${ }^{6}$ We compile all billionaires in US dollars listed at least once between 1996 and 2010 in Forbes Magazine's annual listing of billionaires. In total, there were 1,723 unique such individuals. Some of these individuals cannot be plausibly categorised as entrepreneurs because they did not acquire their wealth by starting and developing one or several companies. Excluding individuals who did not acquire their wealth by starting a company leaves 996 billionaires from a total of 53 countries. We denote such exceptionally successful firm formation and venturing "superentrepreneurship", and the persons behind these firms are called "superentrepreneurs".

The data are then used to compute the number of superentrepreneurs per capita in different countries and regions. In addition, we develop two complementary measures of entrepreneurship: (i) the share of the 100 largest firms in each country founded by an individual entrepreneur in the post-war period and (ii) venture capital investment as a share of GDP.

The paper is organised as follows. Section two describes the method used to collect the data. In section three, we present a theoretical framework that can be used to understand the fundamental difference between self-employment and entrepreneurship. In sections four and five, we present and discuss our main empirical results, and in section six we explain why entrepreneurship and self-employment tend to be negatively related. In the final section, we discuss what we believe are the most important implications and policy conclusions of our study.

\footnotetext{
${ }^{6}$ This paper draws on our earlier research, notably Henrekson and Sanandaji (2014), Sanandaji (2014) and Sanandaji and Leeson (2013). To our knowledge, these are the first studies that attempt to estimate high-impact entrepreneurship through the accumulation of wealth for founders of new business ventures. The current paper is written for a collective volume edited by Antonina Bakardjieva Engelbrekt, Lars Oxelheim and Thomas Persson, The EU's Role in Fighting Global Imbalances (Cheltenham, UK and Northampton, MA: Edward Elgar, forthcoming).
} 


\section{Our measures of entrepreneurship}

Every year, Forbes Magazine collects and publishes a list of all known dollar billionaires in the world. This list is referred to as "The World's Billionaires". Our preferred measure of Schumpeterian entrepreneurship consists of all individual dollar billionaires who appear at least once on the annual list between 1996 and 2010. In total, there were 1,723 unique individuals on the list during this fifteen-year period. Some of them cannot be categorised as entrepreneurs because they did not accumulate their wealth by starting one or several firms. If one excludes these individuals, we end up with 996 billionaires, denoted superentrepreneurs, from 53 countries.

To establish whether or not each of these individuals is a self-made entrepreneur, a number of distinct sources were used. First, Forbes provides a brief description of the source of wealth of each billionaire. In many cases, this background allowed us to exclude individuals with inherited wealth and non-entrepreneurial billionaires from the sample. If the description by Forbes was not sufficient to determine entrepreneurial status, online sources, usually Wikipedia, were consulted. In the rare cases in which the information from Forbes and Wikipedia was insufficient to determine the status of a billionaire, additional library and internet searches were conducted. With a handful of exceptions (primarily for East- and South-Asian billionaires), these steps were sufficient to determine the source of wealth for the billionaires. Out of the 1,723 billionaires, we were unable to find sufficient information on 29 individuals. These individuals were classified as non-entrepreneurs, but additional analyses treating them as entrepreneurs yielded substantively identical results. Forbes reports the country of citizenship and the country of residence for each individual. This information was supplemented with data on the country of birth. When no information on country of birth could be found, the individual's country of birth was assumed to be the same as his or her citizenship.

A majority of the world's entrepreneurs, 58 percent, did in fact acquire their wealth by starting a business. The figure is lower in Europe, 42 percent, than in the U.S., where 65 percent of the dollar billionaires are entrepreneurs. ${ }^{7}$ Most of the billionaires who were not categorised as entrepreneurs acquired their wealth through bequests, and in many cases, these bequests reflected the entrepreneurial successes of the previous generation. Moreover, many of the non-entrepreneurial CEOs who make the list of the world's richest were hired by entrepreneurial start-ups, such as Microsoft's Steve Ballmer. These individuals are not defined as entrepreneurs because they did not found the company. Other non-entrepreneurial billionaires include traders in the financial sector, corporate CEOs, law firm partners and writers/entertainers whose wealth exceeds the one billion dollar threshold. In the rare cases where the source of wealth could not be determined in any way, the individual was coded as a non-entrepreneur.

Our measure has the advantage of enabling us to create a cross-country measure of high-impact entrepreneurship. Other cross-country measures of entrepreneurship generally

\footnotetext{
${ }^{7}$ Acs and Szerb (2009) construct a cross-country index based on the attitudes of the population towards entrepreneurship and the aspirations of business founders. Morck, Stangeland and Yeung (2000) were the first to take advantage of the billionaire data compiled by Forbes Magazine for academic research. Using the data for the year 1993, they found that countries where a higher share of wealth was inherited tended to have lower rates of growth in subsequent years.
} 
rely on various estimates of self-employment or entry into self-employment. Still, our measure of entrepreneurship can be criticised on a number of counts. A first potential problem is that one billion dollars is an excessively high threshold, and many successful entrepreneurs will thereby be inadvertently excluded as a consequence. The choice of this threshold is entirely due to data limitations. Hopefully the extreme tail of the distribution tells us something also about the mean; a country with many more exceptional entrepreneurs is likely to have more "ordinary" entrepreneurs as well. Furthermore, while the billionaire entrepreneurs are few, they are disproportionately important, representing many of the most valuable, innovative and influential firms created.

To examine the robustness of the results, we also consider two other cross-country measures of entrepreneurship. The first alternative measure is the share of the 100 largest firms that were founded by an individual entrepreneur after 1945. The second alternative measure is venture capital investment as a share of GDP, as calculated by Lerner and Tåg (2013). Venture capital investments typically go to innovative and growth oriented firms (Kaplan and Lerner 2010). For this reason, venture capital investment as a share of GDP can be used to approximate how entrepreneurial a country is. Two problems with this measure are that not all entrepreneurial firms receive venture capital and that the size of this sector also depends on how financially sophisticated a country is. Venture capital investment as a share of GDP strongly correlates with per capita billionaire entrepreneurs $(r=0.83)$. This correlation remains high and statistically significant when controlling for per capita income.

Business angels are another important source of finance for startups. There exists less systematic cross-country data on angel investors. OECD (2009b) provides estimates on the number of business angel networks for 23 countries for the year 2007. The number of business angel networks per capita has a statistically significant correlation with per capita billionaire entrepreneurs $(r=0.47)$.

Billionaire entrepreneurs are obviously quite rare. However, they constitute a large percentage of the founders of the largest entrepreneurial firms. Of the 100 largest firms in the United States by market capitalisation, 34 are firms founded by entrepreneurs in the post-war era. ${ }^{8}$ Among these firms, half were founded by the billionaire entrepreneurs on our list. Most of the others are missing from the list not because the founder did not become a billionaire, but because the founder died before 1996, the first year in our database. A similar share of the founders of the largest new entrepreneurial firms in Europe and Japan are on our list of billionaires. The fact that billionaire entrepreneurs are rare reflects the fact that successful Schumpeterian entrepreneurship that leads to large new firms is a rare phenomenon.

American entrepreneurial firms founded in the post-war period include Intel, Microsoft, Apple, Google, Wal-Mart, Home Depot, Starbucks, Bloomberg, Facebook, E-bay, Hewlett-Packard, Amazon, CNN, Fox News, Nike, and FedX. European firms include IKEA, SAP, Aldi, Zara, H\&M, Swatch Group, Virgin Group and Ryanair. Among the Asian firms on the list, one also finds famous brands such as Sony, Honda and Softbank.

According to Puri and Zarutskie (2012), approximately 0.1 percent of all firms in the U.S. receive early-stage financing from specialised venture capitalists. Venture capitalists not only make equity investments in entrepreneurial firms, but they also actively engage in the

\footnotetext{
${ }^{8}$ Own calculations based on Forbes Magazine's list of the largest firms
} 
management and governance of the firms in which they invest. Venture capitalists have a fixed time horizon for their investment. They invest with the express purpose of exiting within three to seven years by selling their equity stake to somebody else or by an initial public offering (IPO; listing on a stock exchange). In the U.S., venture capital firms are especially important in new, knowledge-intensive activities, notably information and communications technology and biotechnology (Gompers and Lerner 2001). In these areas, investments tend to be immaterial and the potential of a specific technology is exceedingly difficult to evaluate. Therefore, outside investors require a great deal of specialist knowledge to assess the market potential of different projects. Once a venture capital firm has decided to provide equity to an entrepreneurial firm, it becomes crucial for the venture firm to also engage in other ways to maximise the likelihood that the venture will succeed. Such engagements take many forms: the supply of management, board membership, market knowledge, etc.

Among the start-ups that became extremely successful and made an IPO, as many as two thirds received venture capital early in their life cycle (Kaplan and Lerner 2010). Thus, a majority of the entrepreneurial firms with great potential were backed by venture capital. Therefore, it appears to be reasonable to use the receipt of venture capital as a proxy for distinguishing entrepreneurial firms with high potential from other firms.

One limitation with our study is that we are only able to measure Schumpeterian entrepreneurship ex post, i.e., when it has already proven successful. We cannot observe how many individuals tried to start entrepreneurial firms. However, we deem it likely that attempts to develop entrepreneurial firms are positively correlated with successful entrepreneurship. From the point of view of the policymaker, we believe that the end result - new large firms is more relevant than the number of failed attempts. This is not to say that the number of failed attempts is uninteresting; such information can be useful for other purposes. Rather, because our focus here is on entrepreneurship policy, what matters most is the final number of successful new firms. The intermediate steps (are there more successful firms because more people had incentives to enter entrepreneurship or because more of the entrants succeeded?) are likely to be of secondary importance. In practice, it is fairly straightforward to distinguish Schumpeterian entrepreneurship from non-entrepreneurial business activity and selfemployment, although it can be quite difficult in the early stage.

The fact that a mere 0.1 percent of all U.S. firms, but two thirds of all firms that execute an IPO, receive venture capital at least once during their life cycle, suggests that the receipt of venture capital financing can be used as an ex ante-indicator (proxy) of entrepreneurial firms with high potential. We will show below that the number of superentrepreneurs per capita and venture capital investment as a share of GDP are highly correlated. This correlation suggests that both measures of Schumpeterian entrepreneurship ex ante and ex post are closely related.

\section{Explaining differences in the rate of entrepreneurship}

How can the cross-country differences in the rate of superentrepreneurship be explained? We hypothesise that explanations for the observed differences emanate from structural factors (population, income levels etc.) and institutional factors such as taxes and regulations, which 
other scholars have identified as important determinants of the rate of entrepreneurship and business activity.

Neither entrepreneurs nor other agents are driven by economic incentives alone. Cultural and psychological factors also play a role. For instance, an entrepreneur may be motivated by a wish to realise a business idea or a project as such. A person may harbour a dream to prove to himself/herself - and to others - that he or she is capable of implementing a vision and achieving success. Social recognition, media attention and the receipt of awards may be important. Joseph Schumpeter (1934) stressed these motives as the most important in addition to the ambition to found a "private empire". However, even if economic profit is not in itself a goal that motivates the entrepreneur, it still fulfils a function as an indicator of success and ability. Economic profit - expected or realised - is also a necessary condition for obtaining resources for innovation and expansion. Thus, even if profit seeking were not a goal in itself, it would nevertheless be a necessary means for anyone striving to realise their entrepreneurial vision in the form of a successful firm.

The prevailing social attitudes vis-à-vis entrepreneurship and business activity are also a reflection of the institutional setup and the incentives they give rise to. For many individuals, the prospect of becoming an entrepreneur does not appear attractive enough relative to other options. The expected rate of return (monetary plus non-monetary) is not perceived to be sufficient to bear the inevitable risk and genuine uncertainty that is an integral part of being an entrepreneur.

Negative attitudes towards entrepreneurship and commercial activity more generally may also be the result of more fundamental factors and deep-seated attitudes. Still, norms and attitudes are culturally codified products of the reward structures in society; institutional changes are likely to affect norms and attitudes. ${ }^{9}$ Furthermore, the importance of culture may not only induce inertia but may also produce a positive reinforcing feedback cycle. A more entrepreneurial culture generates a larger "demonstration effect," a process in which people are exposed to successful entrepreneurs and are in turn stimulated to engage in entrepreneurial activities; soon more people are being stimulated, which even further strengthens the entrepreneurial culture. ${ }^{10}$ Yet causality may run in the opposite direction. A vivid entrepreneurial culture is not a cause but rather a by-product of institutions that foster entrepreneurship. ${ }^{11}$ Culture is a proximate rather than an ultimate cause; focusing on its role in spurring entrepreneurial activity is therefore misleading.

For all countries in our dataset with more than one million inhabitants, we gather data on per capita income, business regulation and taxes. Data on population and purchasing power adjusted by per capita income rates for the year 2009 were obtained from the International Monetary Fund (IMF 2009). To measure national self-employment, we used non-agricultural self-employment rates from the OECD (2009a) for the year 2000, which was the latest year for which a standardised measure was reported. For non-OECD countries, we use data from the most recent year for which ILO data were available (mostly 2007 or 2008). It should be noted that because self-employment rates are stable over time, our empirical

\footnotetext{
${ }^{9}$ Baumol, Litan and Schramm (2007, p. 203ff) and Smith (2003)

${ }^{10}$ Audretsch et al. (2002)

${ }^{11}$ See Boettke and Coyne (2009) for a further discussion.
} 
estimates are not sensitive to the exact year used. The data on trust levels are from the World Value Survey.

The data on business regulations were collected from two sources. For 28 developed countries, the OECD has constructed an index measure referred to as "Administrative burdens on corporations and sole proprietor start-ups", as well as a measure of employment protection regulation (OECD 2005). For most nations in the world, the World Bank estimates a ranking for "the ease of doing business" (World Bank 2010). A low number on the ranking implies more favourable, usually less complex (simpler), regulations for businesses. The corporate tax data are from the same source. To estimate the tax burden imposed on firms, we use the standard statutory corporate tax rate in 2009.

We may note some further potential limitations of these measures of entrepreneurship. First, entrepreneurship need not be productive, as emphasised by Baumol (1990) and Murphy et al. (1991), and as illustrated by events during the economic transition in Russia. This concern is especially pressing in countries with weak institutional environments. As noted, the theoretical definition we aim to capture in this paper is innovation and/or growth in new firms. The empirical strategy relies on the accumulation of extraordinary wealth through the founding of new firms. None of these definitions necessarily signify that the activity is socially valuable. Because most of the entrepreneurs and much of the focus is on industrialised countries with institutions that reward wealth creation rather than rent seeking or predation, this concern is hopefully secondary. A careful inspection of the companies reveals that the incidence of billionaires who acquired their resources through predation rather than innovative/productive entrepreneurship is very low. All of the primary results of this paper hold when the sample is restricted to the OECD countries. This consistency indicates that entrepreneurial activity not only makes the individual entrepreneur wealthy but also contributes significant social value. Moreover, the focus in this paper is on a broad aggregate of wealthy countries in Europe, Asia and the United States.

\section{More self-employed but fewer entrepreneurs in Europe}

Figure 1 displays the rate of non-agricultural self-employment as measured by the OECD in 2008. Mexico, Greece, Italy, South Korea, Turkey and Portugal stand out as the countries with the highest rates of self-employment. Close to one third of the workforce is selfemployed in these countries. By contrast, the U.S. has the second lowest self-employment rate among developed nations. The average rate of self-employment in Western Europe is twice that of the U.S.

Figure 2 instead shows the number of superentrepreneurs per million inhabitants for the same countries. Hong Kong, Israel, the U.S. and Singapore stand out as particularly entrepreneurial, while Western Europe and Japan have a comparatively low number of highimpact entrepreneurs per capita. The number of superentrepreneurs per capita in Europe and Japan is almost exactly one fourth of the U.S. level. Considering that self-employment is often used as a measure of entrepreneurship, the results are quite remarkable: entrepreneurship and self-employment rates among OECD countries are negatively related.

Figure 1 and 2 about here 
The problems with using self-employment to measure entrepreneurship have been recognised. In response, researchers have devised new empirical measures, such as the rate of small business ownership or participation in startups. A prime example is the Global Entrepreneurship Monitor (GEM), which provides detailed cross-country data on recent startup participation (Bosma and Levie 2010). The GEM figures can be interpreted as the flow into the stock of self-employment. The GEM startup rates correlate strongly and positively $(r=0.72)$ with the non-agricultural self-employment rate. By contrast, the GEM measure correlates negatively with our measure of high-impact entrepreneurship $(r=-0.32)$.

Table 1 about here

Table 1 shows correlations between the self-employment rate and five different proxies for entrepreneurship plus GDP per capita. The alternative measures of entrepreneurship include (i) the small business ownership rate, defined as the share of the workforce who own a business in the year 2007 (OECD 20110); (ii) employment in firms with fewer than 10 employees as a share of total employment in 2007 (OECD 2011); (iii) the widely used GEM Total Entrepreneurial Activity (TEA) measure for the years 2001-2010; (iv) the rate of billionaire entrepreneurship per capita; and (v) VC investment as a share of GDP.

Table 1 shows that the measures can be grouped into two categories. The rate of billionaire entrepreneurship per capita, VC investment as a share of GDP and per capita GDP are negatively related to self-employment. The second category consists of three conceptually related measures: the business ownership rate, the small firm employment share and the GEM measure of startup activity. These measures all correlate positively with self-employment. Thus, the problem of self-employment being a poor proxy for high-impact Schumpeterian entrepreneurship is not solved by using empirical metrics that are conceptually close to the self-employment rate such as startup rates or the small business ownership rate.

In Table 2, we summarise the results for the U.S., Europe and Asia. The rate of selfemployment in the U.S. is 50 percent lower than in Europe and Asia, while the number of superentrepreneurs per capita is four times greater. It is striking that our two alternative measures of entrepreneurship provide similar results in regard to the comparison between the U.S. and Europe. Total venture capital investment as a share of GDP is more than five times greater in the U.S. While 34 of the 100 largest American firms were founded by individual entrepreneurs in the post-war period, the corresponding figure for Europe is a mere seven out of 100 .

\section{Table 2 about here}

Europe scores clearly below Asia according to two of the measures of entrepreneurship, but slightly higher when the rate of entrepreneurship is proxied by venture capital investment as a share of GDP.

How can these differences be explained? Is the explanation that there is a less vibrant entrepreneurial culture in Europe or can the explanation be traced to differences in the 
pertinent institutions? The nature of our data and our cross-country measure of entrepreneurship makes it difficult to establish causal links or to answer these questions definitively. We are, however, able to show how the rate of entrepreneurship correlates with institutional factors, which provides important clues to likely explanations and perhaps also guidance for policy.

Overall, richer countries have more superentrepreneurs per capita, although we cannot - given today's stringent methodological demands - establish causality, i.e., that the rich countries are rich because they have more entrepreneurship. A higher GDP per capita may facilitate entrepreneurship, and then more entrepreneurship may lead to a higher GDP per capita. It is therefore likely that countries with better institutions tend to have both higher GDP per capita and more entrepreneurship. Several studies, including our own, strongly suggest that this relationship is the case. Lower taxes on firm profits and a lighter regulatory burden also correlate positively with a higher rate of entrepreneurship.

Countries having more entrepreneurship tend to rank more highly in the World Bank's so-called ease of doing business measure of regulatory burden (having a lower regulatory burden) for newly started firms; see figure 3.

As shown in figure 4, countries characterised by higher generalised trust have more entrepreneurship. In this case, trust can be interpreted as a measure of transaction costs. In a country where citizens tend to distrust each other, it becomes more expensive and more difficult to build large firms. Instead, firms tend to be restricted to a size at which the owner is able to oversee and control the firm's formal and informal relations with employees, customers, suppliers and government authorities. The stronger protection of private property rights is also positively associated with the number of entrepreneurs per capita.

Figure 3 and 4 about here

Differences in the effective taxation of business activity are one of the most important potential explanations for cross-country differences in the business climate and entrepreneurship. ${ }^{12}$ When discussing entrepreneurially driven innovation and taxes, one should keep in mind that the risk of failure is very high. By its very nature, entrepreneurship is characterised by a high risk of failure and a low likelihood of extreme success. Under such circumstances - which may be likened to a tournament with many competitors but few prize winners - taxes on successful entrepreneurship reduce the expected return on success. ${ }^{13}$

This effect is reinforced by the well-documented fact that small firms are good at avoiding high taxes by more or less legal means. However, the capacity for tax evasion or tax avoidance is negatively related to the size of the firm. As a firm expands, the share of the firm's income that the owner can use for private consumption declines, both because the firm must be more professionally administered and because the likelihood of tax auditing increases. Empirical studies (Slemrod and Bakija 2008), even for a law-abiding country such as Sweden (Engström and Holmlund 2009), have systematically shown that high taxes

\footnotetext{
${ }^{12}$ Henrekson and Sanandaji (2015) offer a comprehensive survey of recent research on the effects of owner-level taxes on business activity in general and entrepreneurship in particular.

${ }^{13}$ Persson and Sandmo (2005) show that taxes even on exceptionally high earnings can reduce effort if the probability of obtaining those earnings is small.
} 
stimulate self-employment. This stimulation occurs either because the self-employed have lower tax rates (including mandatory social security payments) relative to employees or because they find it easier to evade taxes because they are self-employed. By contrast, there is no evidence that large entrepreneurial firms evade taxes to a greater extent than the average firm. Chen et al. (2010) show that American entrepreneurs or members of their family that are controlling owners of a public firm - half of all public firms in the U.S. have a controlling owner (Holderness 2009) - are less aggressive in their tax planning than owners of closely held firms. There is thus reason to believe that high taxes lead to more self-employment and small-scale business activity and reduce innovative entrepreneurship with high growth aspirations.

\section{Employees rarely become wealthy}

Should we interpret the relationship as causal, then the European deficit in terms of entrepreneurship relative to the U.S. is explained by differences in these factors. European countries tend to have higher effective tax rates, a greater regulatory burden for start-ups, and a less favourable business climate in several other ways. Hence, contemporary Europe has a less propitious "ecosystem" for innovative entrepreneurship and business activity, which reduces the likelihood that successful entrepreneurs are identified through a competitive selection process and then expand until they reach their full inherent potential.

Silicon Valley and the metropolitan areas of Boston and New York are almost universally considered to be substantially more entrepreneurial than the American average. Almost half of all American superentrepreneurs reside in New York, Massachusetts or California, and the number of billionaires per capita is particularly high in these three states; see table 3. It is therefore of particular interest to examine how well some of the most commonly used measures of entrepreneurship manage to identify the high entrepreneurial activity in these states. To many, the results may appear both surprising and counterintuitive. Relative to the national average, these regions have a lower rate of self-employment, fewer firms per capita, a lower employment share in firms with fewer than 20 employees, and a higher employment share in firms with more than 500 employees. These findings can be interpreted as evidence in favour of our hypothesis that there are more "ordinary" entrepreneurs in a country where there are many superentrepreneurs.

Table 3 about here

Another interesting finding is that an overwhelming majority of the self-made billionaires in wealthy countries have acquired their wealth through successful entrepreneurship and not through salaried employment. This fact is also true for self-made billionaires working in the financial sector, who almost without exception are founders of firms rather than employees. The average wealth of American superentrepreneurs is 2.4 billion dollars, while the average annual salary for the most highly paid CEOs is 23 million dollars.

The fact that such a large proportion of billionaires became wealthy by founding and expanding their own firms rather than by working for somebody else suggests that there are 
fundamental problems that cannot be resolved through contracting. It appears virtually impossible for entrepreneurial top talent to obtain ownership of a large proportion of the total value he or she creates unless he or she owns a sizable share of the firm or firms in which he or she operates. There are few, if any, examples of labour market contracts in which stock options and bonus schemes have created high-powered incentives for employee entrepreneurs comparable to those obtained by successful entrepreneurs when they have sizable equity stakes in the firms that they run.

There are at least two reasons for this state of affairs. The first reason is legitimacy. The other shareholders (and the public as reflected in the media) do not accept extraordinarily large remuneration to employees, not even in cases where the rate of return on their own investment in the firm is extremely high. Telling examples are the controversies surrounding the pension plan of the long-time CEO and chairman of ABB, Percy Barnevik, and the exit bonus awarded to the Novartis chairman Daniel Vasella in 2013. Even if such contracts were accepted by shareholders and the general public, it would still not be possible to make them sufficiently high-powered to handle the principal-agent problems associated with the creation of extraordinary fortunes emanating from entrepreneurship. There appears to exist fundamental economic reasons why exceptional personal wealth creation through revolutionary innovations is disproportionally conducted in new firms. In new firms, the innovator-entrepreneur retains a substantial share of the property rights rather than working as a salaried employee.

\section{Why more entrepreneurship means less self-employment}

Former JC Penney employee and retail franchise operator Sam Walton founded Walmart in 1962, when his idea for establishing discount stores in small town America was rejected by his employer. By 1985, Sam Walton was the richest man in America according to the Forbes Magazine ranking. Walmart grew to be the largest private employer in the world and is estimated to have contributed to a non-negligible share of productivity growth in recent years (Hausman and Leibtag 2009). The Walmart story illustrates the impact that creative entrepreneurship can have on self-employment rates. Its growth was accompanied by, and indeed required, the replacement of thousands of smaller mom-and pop retail operations (Jia 2008). Between 1963 and 2002, when the U.S. population increased by more than 50 percent, the number of single-store retailers in the U.S. declined by over half (Basker 2007).

This pattern is not unique to Walmart; firms such as Home Depot, Gap, Ikea, H\&M and Amazon have similarly reduced the number of self-employed in their industry. Nor is the process unique to the retail sector. Starbucks replaces operations that before its entry and in other countries where it has not yet entered, are managed by a multitude of the self-employed. Even the growth of firms such as Intel, Microsoft and Google, which do not directly compete with a large number of small businesses, reduce self-employment. In their case, the mechanism is offering better career prospects for employees, thus raising the opportunity cost of self-employment. ${ }^{14}$

\footnotetext{
${ }^{14}$ It is also possible for entrepreneurial firms to increase self-employment as an indirect result of technological innovations. Information technology, for example, appears to have lowered the costs of operating a small, independent business. However, this indirect effect is ambiguous and may just as well go the other way when the
} 
It is natural that entrepreneurship reduces the small-business share of employment because each successful entrepreneurial venture results in an increase in the number of large firms. In the process of bringing new innovations to the market, entrepreneurs typically (according to some, by definition) create entirely new organisations with thousands of new high paying jobs, some of which are filled by people who otherwise would work for themselves. The effect is even stronger if the entrepreneurial firm directly competes with small businesses and reduces their share of the product market.

In many industries, the most efficient firms have not grown really large, and thus they have not been able to consolidate the European market. In particular, southern Europe is characterised by a fragmented industry and a firm structure with many small firms, but few entrepreneurial firms that have consolidated markets by growing large.

As already noted, new and entrepreneurially driven firms will offer more attractive and well-paid employment opportunities, which, relatively speaking, reduce the value of becoming and remaining self-employed. If higher taxes reduce the likelihood that new entrepreneurial firms are created that restructure the economy or impede the expansion of large firms, we would expect that countries with high taxes on profits (dividend and capital gains taxes) would have a larger share of their business activity in small, less efficient firms.

The effect of regulation on self-employment and entrepreneurship is in many ways similar to the effect of taxation. Because income in the form of self-employment does not require that the person employed writes a formal contract with his employer, it offers plenty of room for circumventing regulations that may stand in the way of an otherwise mutually beneficial contract. In large firms, however, regulations are likely to be binding, and they can therefore reduce the scope for reaching optimal agreements between the firm and potential employees. This potential scope includes aspects such as total number of working hours (per day, week, month or year), days of paid vacation, working hours, pension rights and other social benefits as well as the rate of pay per unit of time.

In many countries, especially in Europe, firms below a certain threshold are exempted from certain types of regulation. Most importantly, there are exemptions for stringent labour security legislation, which in many countries only applies to firms that have attained a certain size. For instance, there is an important threshold at 50 employees in France, and at 15 employees in Italy and Portugal. ${ }^{15}$ Analogously, the American health care reform in 2010 implies that small firms receive certain subsidies from the Federal government to meet their obligations, but these subsidies will be phased out when firms grow larger. Therefore, this health care reform, inadvertently, gives rise to a de facto surtax on firm growth. In this way, an onerous regulatory burden can impede entrepreneurship aimed at introducing an innovation and penetrating the market by means of a rapidly expanding firm that captures a large market share. Instead, profitability increases for non-entrepreneurial activities, such as self-employment, compared to being a salaried employee in a large firm subject to heavy regulation. Again, more stringent regulation results in a tendency toward increased self-

introduction of new technology lowers transaction costs within large organisations. Another way in which it appears that entrepreneurship can increase self-employment is by creating franchises. However, franchises to date constitute a negligible share of self-employment rates (Price Waterhouse Coopers 2011)

${ }^{15}$ Garicano, Lelarge and Van Reenen (2013), Braguinsky, Branstetter and Regateiro (2011) and Schivardi, and Torrini (2008) for France, Portugal and Italy, respectively 
employment and a larger share of production in small firms where productivity is lower. This relationship occurs exactly because the regulations reduce innovative entrepreneurship and stymie the growth of large firms.

This reverse relationship between entrepreneurship and self-employment only appears paradoxical if one defines entrepreneurship as self-employment. The mechanism is quite straightforward if one instead defines entrepreneurs as individuals who are engaged in innovation, in the founding and development of new firms and with a strong ambition to grow the firm in question to reach its full potential, while self-employment is a contractual form in the labour market that exists for a number of reasons. The most important of these reasons are strong preferences for being one's own boss, the solution to agency problems that are hard to manage and regulate in a standard employment contract, better monitoring of employees in a small firm, and a means to evade high taxes and avoid having onerous regulations applied to employees.

Entrepreneurship is one channel through which firms based on valuable innovations or firms better organised than their competitors can increase their share of the economy. When these superior firms expand, formerly self-employed or small-business owners are replaced and absorbed into salaried employment in more efficient firms. The result is both a more prosperous economy and a lower rate of self-employment.

\section{Boosting superentrepreneurship in Europe}

In this paper, we have shown that self-employment is not only a deficient measure of innovative and growth-oriented entrepreneurship, but that it is outright misleading. This conclusion also holds true for closely related measures such as the business ownership rate and the small firm employment share. Instead, there are strong arguments in favour of using a definition of entrepreneurship based on a broad interpretation of innovation, a definition that also closely relates to the most common interpretation in entrepreneurship theory.

By focusing on Schumpeterian entrepreneurship, we are able to illuminate the imbalance in entrepreneurial activity in Europe relative to the U.S. and to the wealthiest countries in Asia, although the imbalance is much smaller relative to the Asian countries. To put it bluntly, Europe underperforms in regard to entrepreneurship, and this is a drawback for these European economies. Europe's GDP per capita, capital intensity, existing high-tech industries and highly educated workforce provide a fertile ground for making Europe into one of the world's most innovative regions. The fact that there is less innovative entrepreneurship in Europe than one would expect also lowers the rate of growth in the entire world economy because long-run growth is largely driven by innovation.

Policymakers hope that academic research will offer guidance as to how one can stimulate technological change and growth through entrepreneurship policy. For example, the European Commission (2012) maintained that the objective of entrepreneurship is "economic growth, innovation [and] job creation". If entrepreneurship is defined as self-employment or start-up activity per se, one tends to consider entrepreneurship policy as synonymous to SME policy, i.e., policy aimed at promoting small and medium-sized enterprises. However, as our analysis shows, this definition is likely to give rise to potentially grave policy inconsistencies. 
A particular policy may very well encourage firm formation (of small firms without growth ambitions) but discourage entrepreneurship.

Let us conclude by presenting our views - based on our own research, that of others and historical experience - as to how reforms in the European Union may eliminate the global imbalance in the rate of entrepreneurship that we have documented.

- Current tax policies in member countries are perhaps the most important impediment to more innovative entrepreneurship in Europe. Potential superentrepreneurs are rare and tend to have well-paid jobs and career opportunities in incumbent firms, which gives rise to a considerable opportunity cost for the individual who considers founding a new innovative firm. The risk of failure is invariably large. With few exceptions, the founder will be forced to give up a large part of the ownership to financiers and key personnel. To lure a sufficient number of talented people to incur this opportunity cost and to assume the considerable risks involved, economic incentives must be sufficiently strong. Evidence and experience show that the tax system needs to be structured so that the few exceptionally successful cases ex post compensate for the risk and opportunity cost from forgoing an alternate career in an existing firm. The most pertinent taxes are the corporate tax and the capital gains tax because superentrepreneurship is essentially about creating organisations that costefficiently produce highly valued goods and services; from the perspective of the superentrepreneurs (and other equity investors), this translates into a high value for the founded firm. It is likely not a mere coincidence that the entrepreneurial United States has one of the lowest tax rates on long-term capital gains in the world. Among the European countries that fare the best in terms of superentrepreneurship, we find the United Kingdom and Switzerland, two countries where taxes are relatively low. Low capital gains taxes also encourage venture capital investments, which is an essential and integral part of modern innovative entrepreneurship.

- Making superentrepreneurship more worthwhile does not imply that one should reduce incentives for productive self-employment. However, small firms and the selfemployed are more sensitive to other taxes, notably social security fees, VAT and taxation of the owner's own compensation. As regards small-firm taxation, it is important to discourage tax avoidance and tax evasion but refrain from imposing excessively high taxes on business activity. High tax rates combined with ample opportunities for firms to avoid and evade taxes as long as they stay small is likely to hinder successful small-firm owners from even trying to become medium-sized or large.

- Small-firm owners have roughly the same average level of education as the population as a whole. Superentrepreneurship, however, is extremely human capital intensive. In the U.S., one third of superentrepreneurs have a degree from an elite university such as Harvard, Stanford or the University of Chicago, compared to less than one percent of the total labour force. In many cases, superentrepreneurs have an advanced degree in technology or the natural sciences. The dynamic entrepreneurial sector in Silicon Valley has evolved in close cooperation with academic research at neighbouring Stanford University. Next to ill-designed tax systems, the lack of elite 
universities in Europe is the greatest obstacle to increased superentrepreneurship. Consistent with this view is the fact that many European superentrepreneurs have degrees from Oxford and Cambridge, arguably the two best universities in Europe.

- Immigration policy in Europe from non-European countries has focused on refugees and their relatives from low-income countries. In contrast, countries such as Canada, the U.S. and Australia receive a far greater proportion of highly educated and professionally trained immigrants. It is a commonly held belief that immigrants tend to be more entrepreneurial than natives. This belief is not even true in the U.S. In Sweden, for example, the rate of self-employment is roughly similar for immigrants and native Swedes. However, this finding is largely explained by a similar prevalence of non-entrepreneurial self-employment such as hairdressers and restaurants, while immigrants are still underrepresented as founders of rapidly growing firms with many employees. If the goal is for European immigration to provide a boost to entrepreneurship, immigration policies must be modified so that Europe becomes more attractive to highly qualified immigrants. In the 2010s, roughly half of the most highly educated immigrants flowed to the U.S., while less than one fifth ended up in Europe. $^{16}$

- It is likely that the large U.S. domestic market makes it easier to become a superentrepreneur. In practice, a large integrated market implies that a business idea that was developed into a marketable product would become a niche product in small countries like Finland or Slovenia if the firm was confined to the national market. These markets can be contrasted to the integrated U.S. market, which is more than fifty times larger than the Finnish market. In the U.S. case, it is sufficient that one or two retailers, such as Wal-Mart, Home Depot or Target, decide to market the product. Such a decision alone provides the basis for the entrepreneurial firm to take off and embark on a phase of rapid expansion. Because venture capitalists are keenly aware of this advantage, they are more inclined to finance new products and business ideas. However, in Europe the best firms in many industries have not managed to grow to their full potential, thereby consolidating the market, especially in southern Europe, which is characterised by a fragmented market and an industry structure with many small but few truly entrepreneurial firms. The continued integration and consolidation of the national markets in the European Union is therefore good entrepreneurship policy. Pushing for further economic integration of key markets in the member countries would make it possible for the best entrepreneurs and entrepreneurial firms to consider the entire European Union as their domestic market. Integration would arguably be the most effective policy measure to achieve a higher rate of European superentrepreneurship.

- Regulations are commonly modified to make them less stringent for small firms. In Sweden, firms with no more than ten employees are allowed to withhold two employees from the "last-in - first-out" principle in the case of redundancies. Such concessions to small firms are even more pronounced in France and Italy, where firms

\footnotetext{
${ }^{16}$ OECD (2013).
} 
with fewer than 50 and 15 employees, respectively, have less stringent rules. At times, such concessions may be appropriately motivated, particularly in regard to auditing and reporting requirements. Still, laws and regulations that discourage firms from exceeding a certain threshold are a de facto tax on growth. Reasonably successful entrepreneurs are tempted to remain small and avoid the increasing risk that is an inevitable companion to growth. Rules that make it both convenient and economically rational for entrepreneurs to stop growing beyond a certain size harm entrepreneurship. European countries should avoid legislation and regulations that provide incentives for firms to stay small. Rather than granting exceptions from regulations to small firms, European countries ought to make the institutional setup more favourable for firms of all types and all sizes.

An obvious first step when using the rate of self-employment as a measure of entrepreneurship is to make a clear distinction between Schumpeterian/innovative entrepreneurship and non-innovative/replicative self-employment. In our view, policymakers have too often favoured small and medium-sized firms rather than entrepreneurship. A change of focus is an important part of any policy package aimed at raising social welfare and income levels in Europe relative to the most important competitor countries in North America and Asia.

If one country or one region suffers from a lack of potential entrepreneurs, there is a substantial risk that activities that would otherwise have emerged and evolved in that country or region will instead move elsewhere by means of international outsourcing or offshoring. Globalisation and highly integrated markets for goods, services and financial assets make it more important than ever for a country or a region such as Europe to create a favourable business climate. By doing so, the most talented entrepreneurs are incentivised to start new firms and assume risk. Having a knowledge-intensive and profitable entrepreneurial sector leads to the emergence of new entrepreneurs through a number of channels. First, talented entrepreneurs are more inclined to move to cities where there is greater potential for future entrepreneurship. A second source of entrepreneurship is spinoffs from incumbent firms. Many new entrepreneurial firms are formed by key employees in existing entrepreneurial firms that have already grown large. Before Steve Jobs founded Apple, he worked for the computer firm Atari. By working for an established (and successful) firm, potential entrepreneurs acquire experience, knowledge and cutting-edge ideas, i.e., exactly the type of foundation they need to start their own venture.

Weak incentives to exploit entrepreneurial opportunities cannot be offset by spending large resources on education and on subsidies and tax breaks for capital investments. This conclusion is not to deny that a high rate of growth requires more inputs (labour, capital, energy, raw materials). One can therefore observe a strong correlation between economic growth and the amount of inputs. When an entrepreneur develops a new technology and introduces it into the market, capital in the form of machinery and factories as well as workers are needed. These workers may also need highly specialised skills. In this way, the new technology and the products that flow from it increase the demand for input factors in the economy. 
From this observation, it may appear to be reasonable to conclude that growth is driven by the increased supply of inputs. However, that conclusion is unwarranted. An increase in the demand for inputs is an increase that derives from a demand for some products or from a business opportunity exploited by somebody. The change in the demand for labour, capital and other inputs is thus a consequence of the fact that entrepreneurs create and/or perceive business opportunities that they find worth exploiting. Policies that merely increase the supply of labour and capital without promoting entrepreneurship and the development of new technologies would not have the same growth effect. This weak relationship became increasingly clear in the planned economies in Eastern Europe, which began to stagnate in the 1960s despite extremely high investment ratios rates relative to Western countries.

Hence, economic growth and the concomitant increase in social welfare are not driven by increased inputs. Instead, the primary source of growth is provided by entrepreneurs who combine inputs, i.e., factors of production, in new and more valuable ways. An economy can have large deposits of raw materials and an ample supply of financial and human capital, but someone must organise these factors of production and exploit the business opportunities that exist or can be created in the economy. The focus of policymakers should therefore be on the institutional setup and the resulting incentives and not on the supply of factors of production.

What would induce people to save, invest, and acquire highly valued skills and to search for, discover, create and exploit new entrepreneurial opportunities by founding and growing profit-driven firms? First, there are the self-evident factors: a stable macro economy, the rule of law and secure property rights. However, as we have repeatedly stressed in this paper, that is not sufficient. The keys are sound microeconomic incentives for all agents and an institutional setup that fosters productive entrepreneurship. The good news is that there is large potential in Europe for improvements in this respect. Measures that improve the climate for productive entrepreneurship may be politically difficult to enact, but they rarely demand any sacrifices by the population at large.

Our findings also have some bearing on the contentious debate about the performance of the European economy as compared to the United States. Acemoglu et al. (2012) have argued that the U.S. economy is more innovative than Western European welfare states and that American innovativeness benefits Europe and other countries. Thomas Piketty (2014) dismisses Acemoglu et al.'s suggestion. Piketty instead argues that there is little difference between Western Europe and the U.S. in terms of economic performance. Our results support Acemoglu et al. in that the U.S. appears to be significantly more innovative than Western Europe. 


\section{References}

Acemoglu, Daron, James A. Robinson and Thierry Verdier (20012), 'Can't we all be more like Scandinavians? Asymmetric growth and institutions in an interdependent world', NBER Working Paper No. 18441, Cambridge, MA: National Bureau of Economic Research.

Acs, Zoltan J. and László Szerb (2009), 'The Global Entrepreneurship Index (GEINDEX)', Foundations and Trends in Entrepreneurship, 5(5), 341-435.

Audretsch, David B., Marti Carree, André Van Stel and A. Roy Thurik (2002), 'Impeded industrial restructuring: the growth penalty', Kyklos, 55(1), 81-97.

Basker, Emek (2007), 'The causes and consequences of Wal-Mart's growth', Journal of Economic Perspectives, 21(3), 177-198.

Baumol, William J. (1990), 'Entrepreneurship: productive, unproductive and destructive', Journal of Political Economy, 98(5), 893-921.

Baumol, William J. (2002), The Free-Market Innovation Machine: Analyzing the Growth Miracle of Capitalism, Princeton, USA: Princeton University Press.

Baumol, William J. (2010), The Microtheory of Innovative Entrepreneurship, Princeton, NJ: Princeton University Press.

Baumol, William J., Robert E. Litan and Carl J. Schramm (2007), Good Capitalism, Bad Capitalism and the Economics of Growth and Prosperity, New Haven, CT: Yale University Press.

Becker, Sasha O. and Hans K. Hvide (2013), 'Do entrepreneurs matter?', Warwick Economic Research Papers No. 2002, University of Warwick.

Boettke, Peter J. and Christopher Coyne (2009), 'Context matters: institutions and entrepreneurship', Foundations and Trends in Entrepreneurship, 5(2), 135-209.

Bosma, Niels S. and Jonathan Levie (2010), Global Entrepreneurship Monitor 2009: Executive Report, Babson Park, MA: Babson College; Santiago, Chile: Universidad del Desarollo; Reykjavík, Iceland: Háskólinn Reykjavík University; London, UK: Global Entrepreneurship Research Association.

Braguinsky Serguey, Lee G. Branstetter and André Regateiro (2011), 'The incredible shrinking Portuguese firm', NBER Working Paper 17265, Cambridge, MA: National Bureau of Economic Research.

Braunerhjelm, Pontus (2012), 'Innovation and growth', in Martin Andersson, Börje Johansson and Hans Lööf (eds), Innovation and Growth: From R\&D Strategies of Innovating Firms to Economy-Wide Technological Change, London, UK: Oxford University Press, pp. 286-316.

Carree, Martin and A. Roy Thurik (2010), 'The impact of entrepreneurship on economic growth', in Zoltan J. Acs and David B. Audretsch (eds), Handbook of Entrepreneurship Research. New York, NY and London, UK: Springer, pp. 437-471.

Chen, Shuping, Xia Chen, Qiang Cheng and Terry Shevlin (2010), 'Are family firms more tax aggressive than non-family firms?', Journal of Financial Economics, 95(1), 41-61.

Engström, Per and Bertil Holmlund (2009), 'Tax evasion and self-employment in a high-tax country: evidence from Sweden', Applied Economics, 41(19), 2419-2430.

European Commission (2012), Restructuring in Europe 2011, SEC(2012) 59 final. Brussels.

European Commission (2013), Communication from the Commission to the European Parliament, The Council, The European Economic and Social Committee and the Committee of the Regions: Entrepreneurship 2020 Action Plan: Reigniting the entrepreneurial spirit in Europe, COM(2012) 795 final. Brussels. 
Garicano, Luis., Clarie Lelarge and JohnVan Reenen (2013), 'Firm size distortions and the productivity distribution: evidence from France', CEPR Discussion Paper 9495, London, UK: Centre for Economic Policy Research.

Gartner, William B. (1990), 'What are we talking about when we talk about entrepreneurship?', Journal of Business Venturing, 5(1), 15-28.

Gault, Fred (2013), 'Innovation indicators and measurement: an overview', in Fred Gault (ed.), Handbook of Innovation Indicators and Measurement, Cheltenham, UK and Northampton, MA: Edward Elgar, pp. 3-37.

Gompers, Paul A. and Josh Lerner (2001), The Money of Invention: How Venture Capital Creates New Wealth, Cambridge, MA: Harvard Business School Press.

Hall, Bronwyn H. (2011), Using Productivity Growth as an Innovation Indicator, Report for the High Level Panel on Measuring Innovation, Brussels: DG Research, European Commission.

Hausman, Jerry and Ephraim Leibtag (2009), 'CPI Bias from Supercenters: Does the BLS Know that Wal-Mart Exists?', in W. Erwin Diewert, John S. Greenlees and Charles R. Hulten (eds), Price Index Concepts and Measurement, NBER Book Series Studies in Income and Wealth, Chicago, IL: University of Chicago Press, pp. 203-231.

Hébert, Robert F. and Albert N. Link (2006), 'The entrepreneur as innovator', Journal of Technology Transfer, 31(5), 589-597.

Henrekson, Magnus and Jesper Roine (2007), 'Promoting entrepreneurship in the welfare state', in David B. Audretsch, Isabel Grilo and A. Roy Thurik (eds), Handbook of Research on Entrepreneurship Policy, Cheltenham, UK and Northampton, MA: Edward Elgar, pp. 64-93.

Henrekson, Magnus and Tino Sanandaji (2014), 'Small business activity does not measure entrepreneurship', Proceedings of the National Academy of Sciences of the United States of America (PNAS), 111(5), 1760-1765.

Henrekson, Magnus and Tino Sanandaji (2015), 'Owner-level taxes and business activity', Foundations and Trends in Entrepreneurship, forthcoming.

Holcombe, Randall G. (2007), Entrepreneurship and Economic Progress, New York, NY: Routledge.

Holderness, Clifford G. (2009), 'The myth of diffuse ownership in the United States', Review of Financial Studies, 22(4), 1377-1408.

Hurst, Erik and Benjamin Pugsley (2011), 'What do small businesses do?', Brookings Papers on Economic Activity, Fall, 73-118.

IMF (2009), 'World Economic Databases', available at: http://www.imf.org/external/ns/cs.aspx?id=28.

Jia, Panle (2008), 'What happens when Wal-Mart comes to town: an empirical analysis of the discount retailing industry', Econometrica, 76(6), 1263-1316.

Kaplan, Steven and Josh Lerner (2010), 'It ain't broke: the past, present, and future of venture capital', Journal of Applied Corporate Finance, 22(1), 36-47.

Kirzner, Israel M. (1973), Competition and Entrepreneurship, Chicago, IL: University of Chicago Press.

Knight, Frank H. (1921), Risk, Uncertainty and Profit, Boston, MA: Houghton Mifflin Company.

Lerner, Josh and Antoinette Schoar (eds) (2010), International Differences in Entrepreneurship, Chicago, IL: University of Chicago Press.

Lerner, Josh and Joacim Tåg (2013), 'Institutions and venture capital', Industrial and 
Corporate Change, 22(1), 153-182.

Morck, Randall K., David Stangeland and Bernard Yeung (2000), 'Inherited wealth, corporate control, and economic growth: the Canadian disease?', in Randall K. Morck (ed.), Concentrated Corporate Ownership, Chicago, IL: University of Chicago Press, pp. 319371.

Moretti, Enrico (2012), The New Geography of Jobs, New York, NY: Houghton Mifflin Harcourt.

Moretti, Enrico and Per Thulin (2013), 'Local multipliers and human capital in the United States and Sweden'. Industrial and Corporate Change, 22(1), 319-362.

Murphy, Kevin, Andrei Shleifer and Robert Vishny (1991), 'The allocation of talent: implications for growth', Quarterly Journal of Economics, 106(2), 503-530.

OECD (2005), Economic Policy Reforms: Going for Growth, Paris, France: OECD.

OECD (2009a), Overview: Data on Informal Employment and Self-Employment, Paris, France: OECD.

OECD (2009b), Measuring Entrepreneurship: A Collection of Indicators, 2009 edition, Paris, France: OECD.

OECD (2010), The OECD Innovation Strategy: Getting a Head Start on Tomorrow, Paris, France: OECD.

OECD (2011), Entrepreneurship at a Glance 2011, Paris, France: OECD.

OECD (2013), International Migration Outlook 2013, Paris, France: OECD.

Persson, Mats and Agnar Sandmo (2005), 'Taxation and tournaments', Journal of Public Economic Theory, 7(4), 543-559.

Piketty, Thomas (2014), Capital in the Twenty-First Century, Cambridge, MA: Harvard University Press.

Price Waterhouse Coopers (2011), 'Franchise Business Economic Outlook: 2011', available at: http://emarket.franchise.org/News_Release/Franchise\%20Business\%20Outlook\% 20Report\%202011\%20final.pdf.

Puri, Manju and Rebecca Zarutskie (2012), 'On the life cycle dynamics of venture-capital-and non-venture-capital-financed firms', Journal of Finance 67(6), 2247-2293.

Sanandaji, Tino and Peter T. Leeson (2013), 'Billionaires', Industrial and Corporate Change, 22(1), 313-337.

Sanandaji, Tino (2014), 'The international mobility of billionaires', Small Business Economics, 42(2), 329-338.

Schivardi, Fabiano and Roberto Torrini (2008), 'Identifying the effects of firing restrictions through size-contingent differences in regulation', Labour Economics, 15(3), 482-511.

Schumpeter, Joseph A. (1911 [1934]), The Theory of Economic Development, New Brunswick, NJ and London, UK: Transaction Publishers.

Shane, Scott (2008), The Illusions of Entrepreneurship: The Costly Myths that Entrepreneurs, Investors, and Policy Makers Live By, New Haven, CT: Yale University Press.

Slemrod, Joel and Jon Bakija (2008), Taxing Ourselves: A Citizen's Guide to the Debate over Taxes, 4th Edition, Cambridge, MA: MIT Press.

Smith, Vernon (2003), 'Constructivist and ecological rationality in economics', American Economic Review, 93(3), 465-508.

World Bank (2010), Doing Business 2010, Washington, DC: World Bank. 
Figure 1 Self-Employment as a Share of Total Employment Excluding the Agricultural Sector in the OECD in 2008 (\%)

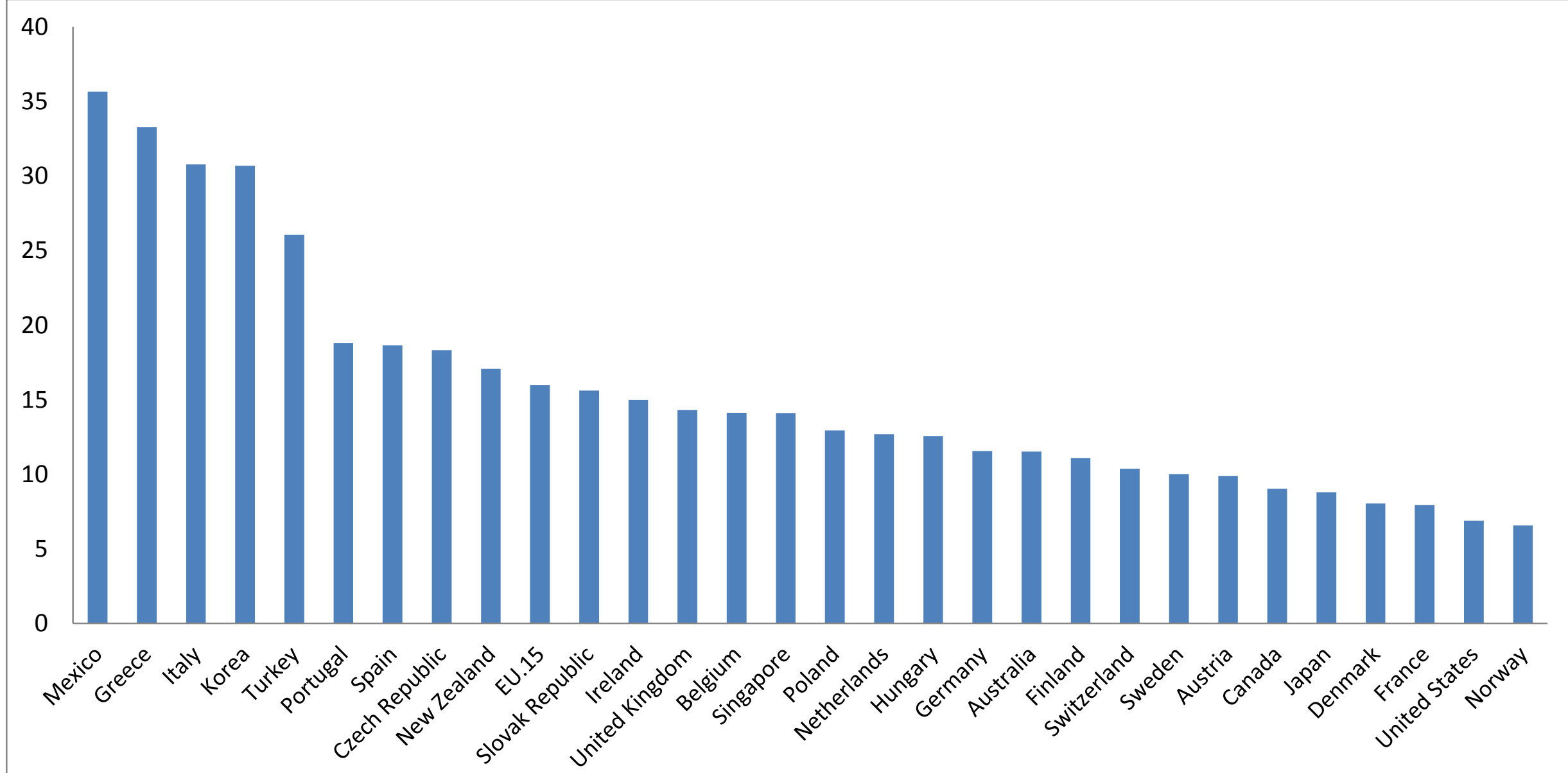

Source: OECD 
Figure 2 The Rate of Entrepreneurship: Number of Superentrepreneurs per Million Inhabitants, 1996-2010

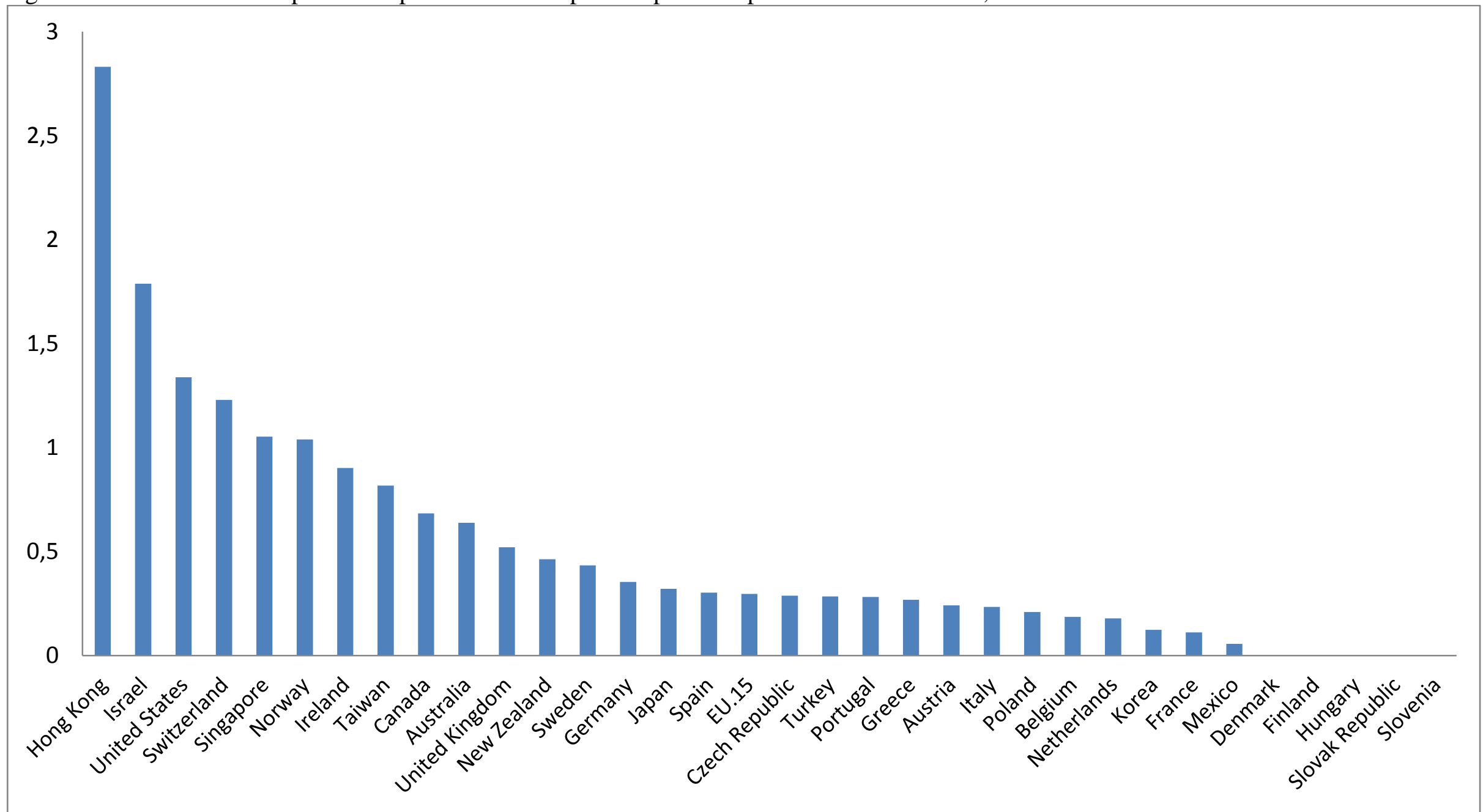

Source: Henrekson and Sanandaji (2014) 
Figure 3 Entrepreneurship and the Regulatory Burden on Firms, OECD Countries

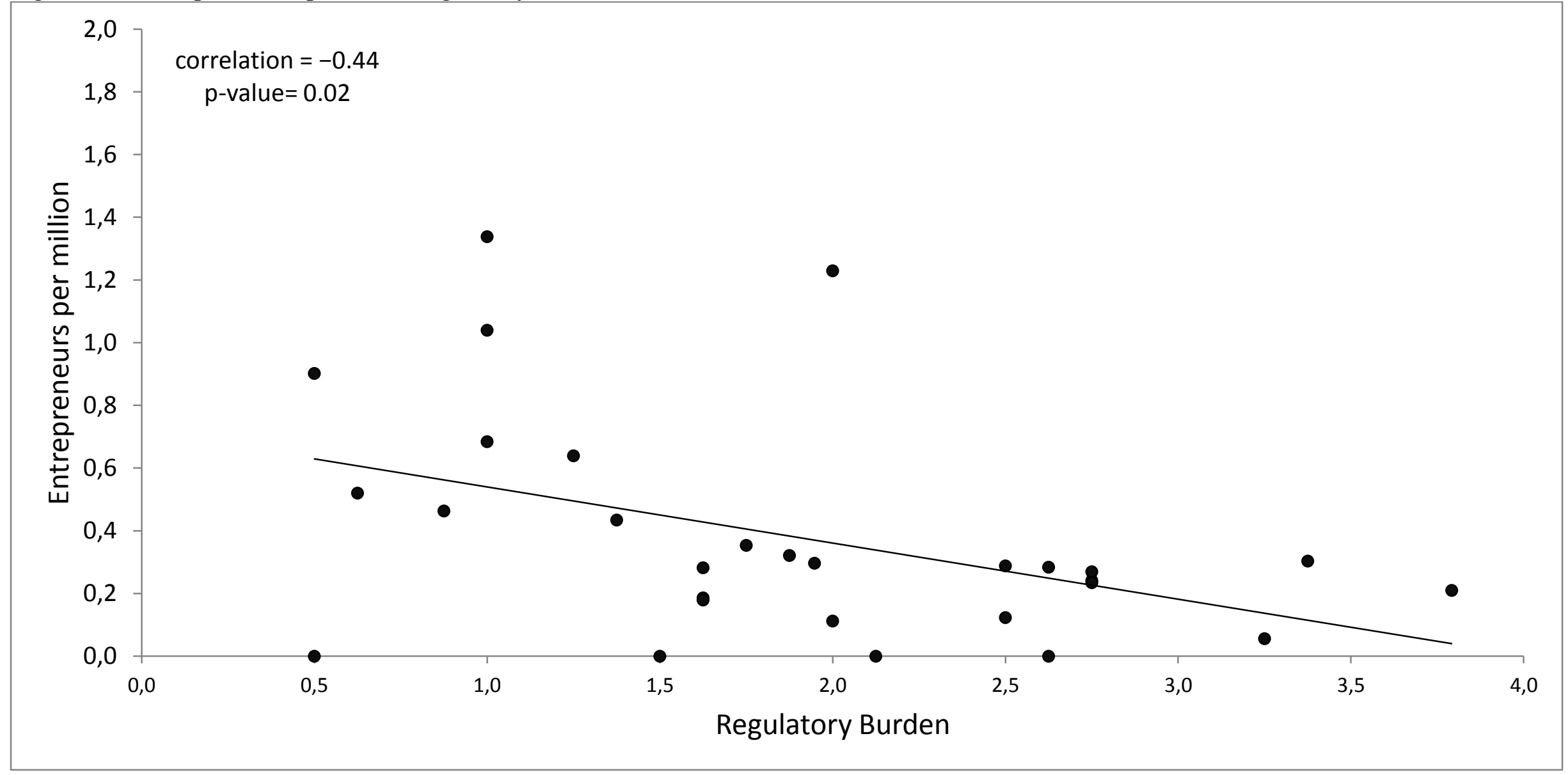


Figure 4 Entrepreneurship and Trust, OECD Countries

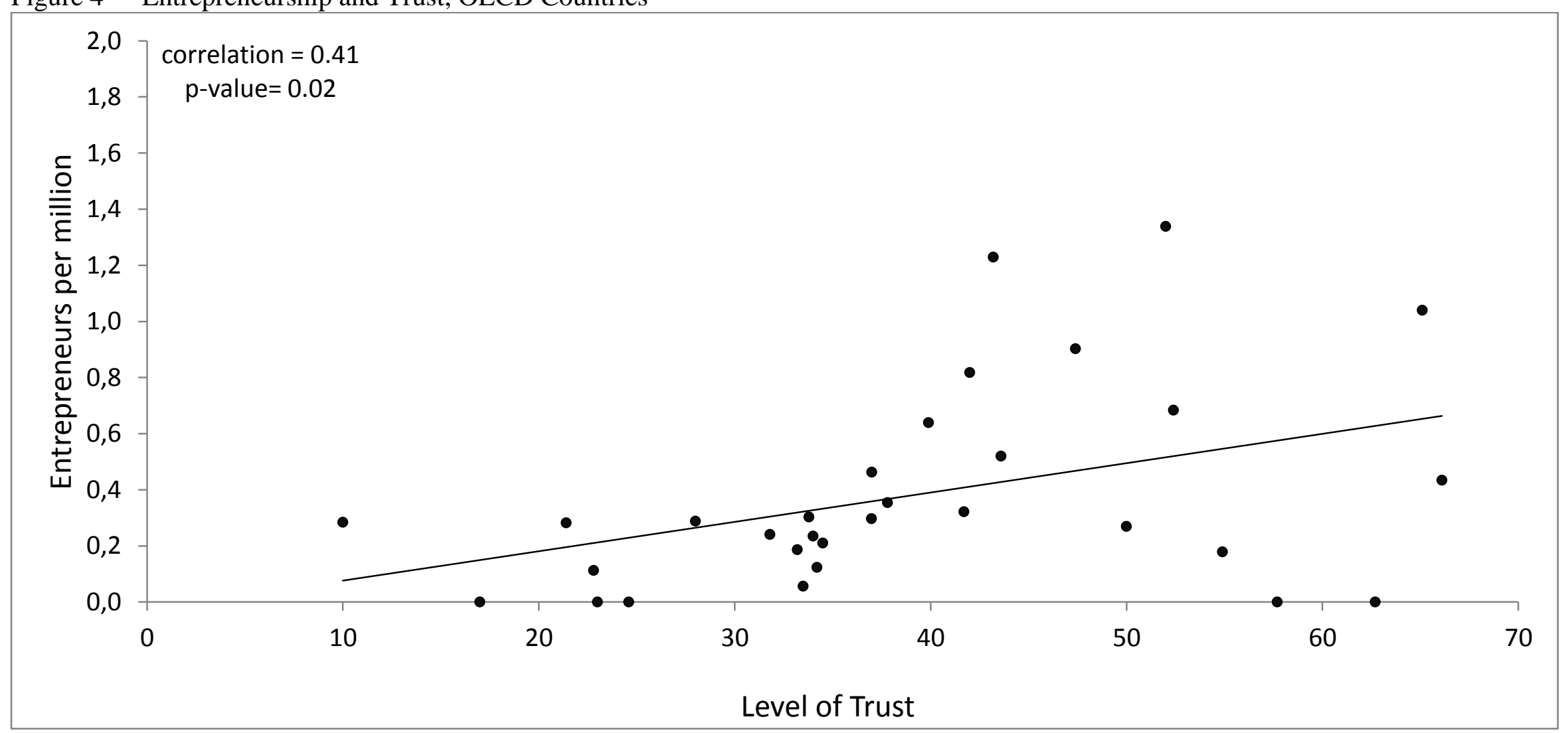


Table 1 The Correlation between Self-Employment and Other Entrepreneurship Proxies

\begin{tabular}{lr}
\hline Entrepreneurship Proxies & \\
\hline Small business ownership rate & 0.69 \\
Small firm employment share & 0.30 \\
Start-up rate (GEM TEA) & 0.72 \\
Billionaire entrepreneurs per capita & -0.33 \\
Venture capital investment as a share of GDP & -0.21 \\
GDP per capita & -0.63 \\
\hline
\end{tabular}

Sources and definitions: See the main text 
Table 2 Entrepreneurship in the United States, Wealthy Asian countries and Western Europe According to Three Different Measures

\begin{tabular}{lrrrrrr}
\hline & $\begin{array}{r}\text { No. of super- } \\
\text { entrepreneurs }\end{array}$ & $\begin{array}{r}\text { Population in } \\
\text { millions }\end{array}$ & $\begin{array}{r}\text { Superentrepre- } \\
\text { neurs per million } \\
\text { inhabitants }\end{array}$ & $\begin{array}{r}\text { Share of the 100 largest } \\
\text { firms founded by an } \\
\text { entrepreneur since 1945 }\end{array}$ & $\begin{array}{r}\text { Venture capital } \\
\text { investment, \% of } \\
\text { GDP 2010 }\end{array}$ & $\begin{array}{r}\text { Self-em- } \\
\text { ployment }\end{array}$ \\
\hline U.S.A. & 411 & 307 & 1.34 & $34 \%$ & 0.200 & $7.5 \%$ \\
Asia* & 91 & 211 & 0.43 & $13 \%$ & 0.024 & $16 \%$ \\
Europe & 132 & 407 & 0.32 & $7 \%$ & 0.036 & $15 \%$ \\
\hline
\end{tabular}

Note: * Japan, South Korea, Taiwan, Singapore and Hong Kong

\# Germany, France, United Kingdom, Italy, Spain, the Netherlands, Greece, Belgium, Portugal, Sweden, Austria, Denmark, Finland, Ireland, Luxembourg, Switzerland,

Norway and Iceland

Source: Henrekson and Sanandaji (2014) 
Table 3 Characteristics of American Superentrepreneurs.

\begin{tabular}{|c|c|c|c|c|c|}
\hline \multicolumn{2}{|c|}{ Educational attainment $(\%$} & \multicolumn{2}{|c|}{$\begin{array}{r}\text { Billionaire } \\
\text { entrepreneurs }\end{array}$} & $\begin{array}{r}\text { Self- } \\
\text { employed }\end{array}$ & $\begin{array}{l}\text { alaried } \\
\text { orkers }\end{array}$ \\
\hline \multicolumn{3}{|c|}{ High school or less } & 6.1 & 31.6 & 36.8 \\
\hline \multicolumn{3}{|c|}{ Some college } & 10.4 & 17.6 & 17.1 \\
\hline \multicolumn{3}{|l|}{ College degree } & 38.5 & 34.3 & 33.6 \\
\hline \multicolumn{3}{|l|}{ Advanced degree } & 45.0 & 16.5 & 12.5 \\
\hline \multicolumn{6}{|c|}{ Source of wealth by industry (share in \%) } \\
\hline Finance & 23.1 & Real estate & 10.5 & Health care & 1. \\
\hline Manufacturing & 18.5 & Mining, oil \& gas & 6.1 & $\begin{array}{l}\text { Professional \& } \\
\text { technical services }\end{array}$ & $\begin{array}{l}1 . \\
9\end{array}$ \\
\hline (of which IT) & 6.6 & Art \& entertainm. & 3.6 & Construction & 1. \\
\hline Information & 17.0 & $\begin{array}{l}\text { Accommodation \& } \\
\text { food services }\end{array}$ & 3.2 & Wholesale trade & $\begin{array}{l}1 . \\
2\end{array}$ \\
\hline (of which IT) & 9.2 & Transportation & 2.9 & Forestry \& agricult. & $\begin{array}{r}1 . \\
0\end{array}$ \\
\hline \multicolumn{3}{|c|}{ Geographic region } & No. & \multicolumn{2}{|c|}{ Relative to population } \\
\hline \multicolumn{2}{|c|}{ Northeast } & \multicolumn{2}{|c|}{109} & & 1.44 \\
\hline \multirow{2}{*}{\multicolumn{2}{|c|}{$\begin{array}{l}\text { (of which New York) } \\
\text { (of which Massachusetts) }\end{array}$}} & \multicolumn{2}{|c|}{76} & & 2.85 \\
\hline & $\begin{array}{l}\text { (of which Massachusetts) } \\
\text { Midwest }\end{array}$ & \multicolumn{2}{|c|}{13} & & 1.45 \\
\hline \multicolumn{2}{|l|}{ Midwest } & \multicolumn{2}{|c|}{56} & & 0.61 \\
\hline \multicolumn{2}{|l|}{ South } & \multicolumn{2}{|c|}{104} & & 0.71 \\
\hline \multicolumn{2}{|l|}{ (of which Texas) } & \multicolumn{2}{|c|}{36} & & 1.17 \\
\hline \multicolumn{2}{|l|}{ West } & \multicolumn{2}{|c|}{137} & & 1.48 \\
\hline \multicolumn{2}{|c|}{ (of which California) } & \multicolumn{2}{|c|}{99} & & 2.02 \\
\hline
\end{tabular}

Note: Educational attainment refers to population aged 25+. Entrepreneurs are assigned to states based on Forbes' designation. If Forbes did not specify a state, this assignment is based on residence.

Relative to population is defined as the share of total entrepreneurs divided by the population share of state/region 1996-2009. 


\section{Short author biographies}

MAGNUS HENREKSON is a professor and president of the Research Institute of Industrial Economics (IFN). Until 2009, he was Jacob Wallenberg Professor at the Department of Economics at the Stockholm School of Economics. Since the end of the 1990s, Magnus's primary research field has been entrepreneurship economics, and he has published a number of scientific articles focused on this area.

TINO SANANDAJI holds a $\mathrm{PhD}$ from the University of Chicago, where he defended his dissertation Essays in Entrepreneurship Policy in 2011. He is a research scholar at the Research Institute of Industrial Economics (IFN). He has a Master's degree from the Stockholm School of Economics (2003). Aside from entrepreneurship economics, Tino's main field is public economics. 